\section{Flowering of Apple Trees in the Second Year Is Increased by First- year P Fertilization}

\author{
G.H. Neilsen', E.J. Hogue', and P. Parchomchuk ${ }^{2}$ \\ Agriculture Canada Research Station, Summerland, B.C. \\ VOH 1ZO, Canada
}

Additional index words. planting hole $\mathrm{P}$, fertigation, leaf $\mathrm{P}$, dwarfing rootstock, Malus domestics

\begin{abstract}
Application of high rates of $P$ in the year of planting increased the number of flower clusters and fruit set the subsequent year on newly planted 'Macspur McIntosh', 'Summerland Red McIntosh', 'Jonagold', and 'Jonamac' apple (Malus domestica Borkh.) on dwarfing rootstock (M.26 and M.9) in three separate experiments. The effect occurred whether $P$ was applied at rates of 36 or $48 \mathrm{~g} P /$ tree as granular monoammonium phosphate (11 N-23.6 P-0K) uniformly mixed with 100 or 180 liter of soil in the planting hole or at rates of 17.5 and $35 \mathrm{~g} \mathrm{P}$ applied as soluble ammonium polyphosphate $(10 \mathrm{~N}-14.6 \mathrm{P}-0 \mathrm{~K})$ with the irrigation water. A leaf $P$ concentration range between $0.20 \%$ and $0.36 \%$ was associated with the acceleration of fruiting.
\end{abstract}

The success of high-density apple plantings on dwarfing rootstock is closely related to achieving early fruit production and economic return. Management practices, including fertilization, that accelerate the onset of fruiting would result in economic advantages. Some research, especially for young fruit trees, has indicated that $\mathrm{P}$ fertilization has improved growth of apple seedlings on replant disease sites (Sewell et al., 1988; Slykhuis and Li, 1985), generated more blossoms in young apple (Bould and Parfitt, 1973; Williams and Thompson, 1979), and increased early yield in apple and peach (Taylor, 1975; Taylor and Goubran, 1975). There is also much evidence that most temperate trees fruits, especially in mature trees, are unlikely to respond to $\mathrm{P}$ fertilization (Childers, 1966). Neilsen et al. (1989) recently demonstrated a role for P in the establishment and early yield of 'McIntosh' and 'Delicious' apple trees irrigated with wastewater containing a high $\mathrm{P}$ concentration. With the apparent mobility of trickle-applied $\mathrm{P}$ in sandy soils (Klein and Spieler, 1987b), the addition of $\mathrm{P}$ with irrigation water (fertigation) might be an appropriate method of $\mathrm{P}$ application to young trees. It therefore seemed important to assess the role of $\mathrm{P}$ in augmenting the number of blossoms and increasing early fruit set of apples on dwarfing rootstock. Emphasis was placed upon testing the effects under field conditions in soils with a range of $\mathrm{P}$ and not exhibiting replant problems, rather than in sand culture. Three

Received for publication 15 Dec. 1989. Contribution no. 746 of Agriculture Canada, Research Station, Summerland, B.C. We acknowledge the field assistance of G. Owen and W. Peters and lab assistance of B. Drought and M. Schulze. The cost of publishing this paper was defrayed in part by the payment of page charges. Under postal regulations, this paper therefore must be hereby marked advertisement solely to indicate this fact. 'Research Scientist.

${ }^{2}$ Research Engineer. field experiments were therefore undertaken to test the effects of $\mathrm{P}$ applied in the planting hole or via irrigation water on acceleration of the onset of fruiting.

$P$ vs. no $P$ in planting hole (expt. 1, Apr. 1986). Sixteen replicates of each of two planting hole fertilizer treatments were applied to 'Macspur McIntosh' on M.26 rootstock. The trees were planted outdoors in 0.6 $\times 0.6 \times 0.5 \mathrm{~m}$ (depth) woven polypropylene bags placed within two trenches. As part of a larger tree removal experiment, the bagged trees were spaced at $1.2 \mathrm{~m}$ in two rows separated by $2 \mathrm{~m}$. Fertilizer treatments were either NP [16.5 g N and $36 \mathrm{~g} \mathrm{P}$, applied as $150 \mathrm{~g}$ of monoammonium phosphate $(11 \mathrm{~N}$ 23.6P-0K)] or equivalent $\mathrm{N}$ [16.5 g N applied as $48.5 \mathrm{~g}$ ammonium nitrate $(34 \mathrm{~N}-0 \mathrm{P}-$ $0 \mathrm{~K})]$. Fertilizers were uniformly mixed throughout the 180 liter of planting soil used for each tree.

Skaha sandy loam soil (Kelley and Spilsbury, 1949) was used as the planting soil in each bag. This soil had not previously been planted to orchard and was characterized by a $\mathrm{pH}$ ( 1 soil :2 water) of 7.2 and a low acid extractable $P$ concentration $\left(18 \mu \mathrm{g} \cdot \mathrm{g}^{-1}\right)$. After planting, the bags were backfitled with soil from the immediate site. Trees were irrigated frequently (every 2 nd day in midseason) by hand from 1 May to 1 Oct. to prevent water stress. A broadcast application of $\mathrm{N}$ as ammonium nitrate at $100 \mathrm{~kg} \mathrm{~N} / \mathrm{ha}$ was made in

Table 1. Effect of $P$ fertilization of young apple trees on number of flower clusters, flower intensity, and fruit set in 2nd-year and 1st-year leaf $\mathbf{N}$ and $\mathrm{P}$ concentration for planting hole $\mathrm{P}$ treatments (expt. 1).

\begin{tabular}{|c|c|c|c|c|c|}
\hline \multirow{2}{*}{$\begin{array}{l}\text { P applied } \\
\text { (g/tree) }\end{array}$} & \multirow{2}{*}{$\begin{array}{c}\text { Flower } \\
\text { clusters } \\
\text { (no./tree) } \\
\end{array}$} & \multirow{2}{*}{$\begin{array}{c}\text { Flower } \\
\text { intensity } \\
\text { (no. } / \mathrm{cm}^{2} \text { ) }\end{array}$} & \multirow{2}{*}{$\begin{array}{c}\text { Fruit set } \\
\text { (no./tree) }\end{array}$} & \multicolumn{2}{|c|}{ Leaf } \\
\hline & & & & $\mathrm{N}$ & $\mathrm{P}$ \\
\hline & & & & \multicolumn{2}{|c|}{$(\% d r y w t)$} \\
\hline 0 & 14.3 & 6.6 & 1.9 & 2.23 & 0.20 \\
\hline 36 & 61.9 & 29.2 & 6.8 & 2.19 & 0.26 \\
\hline SE & 10.0 & 3.8 & 1.2 & 0.02 & 0.02 \\
\hline Significance & $* * *$ & $* * *$ & $*$ & NS & NS \\
\hline
\end{tabular}

NS,*,***Nonsignificant or significant at $P=0.05$ or 0.001 , respectively. trickle-irrigated during the growing season
May 1987 to the surface $0.36-\mathrm{m}^{2}$ area centered on each bagged tree.

Phosphorus-cultivar/rootstock interaction (expt. 2, May 1988). Five replicates of each of three cultivar-rootstock combinations were planted as main plot units in a split-plot design with two planting hole fertilizer treatments, each consisting of threetree plots randomized as subplots within the main plot units. Trees were planted at $1 \mathrm{~m}$ spacing within subplots with each subplot separated by $2 \mathrm{~m}$ in four rows each separated by $3 \mathrm{~m}$. The cultivar-rootstock combinations were 'Jonagold' on M.26 and M.4 and 'Jonamac' on M.26. The two fertilizer treatments were either $200 \mathrm{~g}$ of $11 \mathrm{~N}-23.6 \mathrm{P}-0 \mathrm{~K}$ (48 g $\mathrm{P}$ and $22 \mathrm{~g} \mathrm{~N})$ or $65 \mathrm{~g} \mathrm{34N-0P-0K} \mathrm{(22} \mathrm{g} \mathrm{N)}$ uniformly mixed in the 100 liter of soil for each planting hole. Subsequent fertilization was typical of normal commercial orchard practices with $100 \mathrm{~kg} \mathrm{~N} / \mathrm{ha}$ surface-applied as $34 \mathrm{~N}-0 \mathrm{P}-0 \mathrm{~K}$ in a $1 \times 3-\mathrm{m}$ area centered on each tree on 17 May 1988 and 3 May 1989. The soil at the experimental site was a Skaha sandy loam from which an orchard had been removed 15 years previously. Irrigation from 1 May to 1 Oct. each year was supplied by overhead sprinklers scheduled to apply $\approx 35 \mathrm{~mm}$ of water every 5 days.

$P$ and $N$ combinations in irration water (expt. 3, Apr. 1988). A block of 'Summerland Red McIntosh' on M.9 rootstock was planted at a $1.5-\mathrm{m}$ (within row) by $4.0-\mathrm{m}$ (between row) spacing. A factorial experiment with two N $(23.5 \mathrm{~g} /$ tree, $\mathrm{N} 1 ; 47.0 \mathrm{~g} /$ tree, N2) and three P levels $(0 \mathrm{~g} /$ tree, $\mathrm{P} 1$; $17.5 \mathrm{~g} /$ tree, P2; $35.0 \mathrm{~g} /$ tree, P3) was arranged in a randomized block design with four replicates, each containing six trees. Rows of pollenizer trees surrounded the experimental planting and separated each experimental plot. The fertilizer treatments were applied in four equal weekly doses in May 1988 with the irrigation water. Liquid ammonium polyphosphate (APP, 10N-14.6P$0 \mathrm{~K}$ ) was used as the $\mathrm{P}$ source, while $\mathrm{N}$ in excess of that applied by APP was provided by dissolving sufficient ammonium nitrate (34N-0P-0K) to achieve the $\mathrm{N} 1$ and $\mathrm{N} 2$ rates. The experimental site had previously been in orchard but had been fallow for $\approx 10$ years before we planted the trees. The soil at the site was a Rutland gravelly sand loam (Kelley and Spilsbury, 1949) with a pH (1 soil : 2 water) averaging 6.3 and Bray extractable $P$ average of $25 \mu \mathrm{g} \cdot \mathrm{g}^{-1}$ in the surface 0 to $15-\mathrm{cm}$ depth at planting time. The trees were 
Table 2. Effect of $P$ fertilization of apple trees in 1st year and cultivar-rootstock combination on number of flower clusters, flower intensity, and fruit set in 2 nd year; also, 1st-year leaf $\mathrm{N}$ and $\mathrm{P}$ concentration (expt. 2).

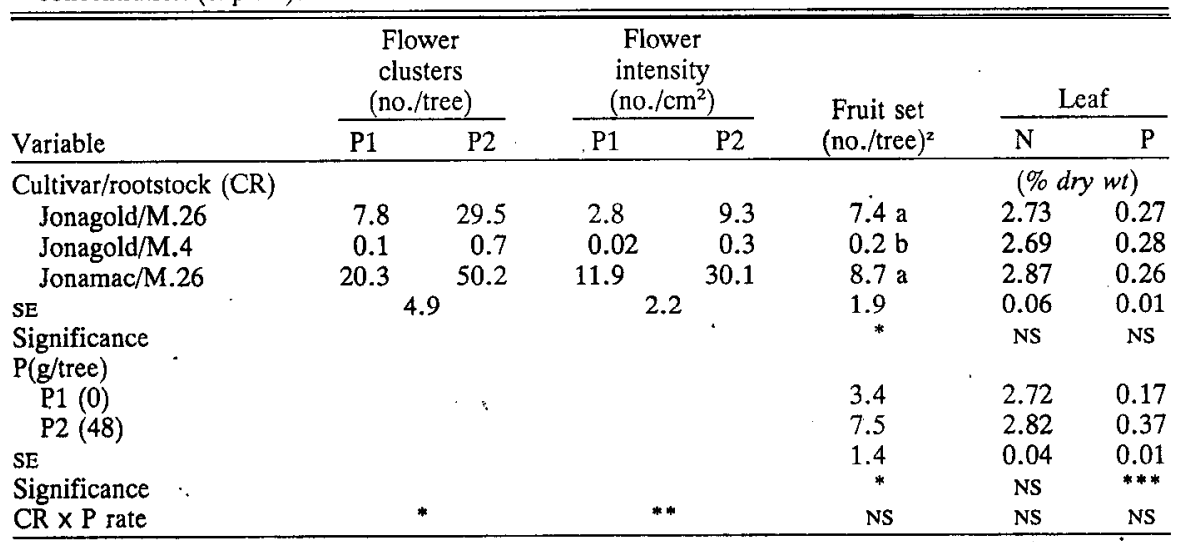

${ }^{2}$ Mean separation by Duncan's multiple range test, $P=0.05$.

Ns,*;******Nonsignificant or significant at $P=0.05,0.01$, or 0.001 , respectively.

Table 3. Effect of $P$ fertilization of apple trees in 1st year on number of flower clusters, flower intensity, and fruit set in 2nd-year and 1st-year leaf $\mathrm{N}$ and $\mathrm{P}$ concentration (expt. 3).

\begin{tabular}{|c|c|c|c|c|c|}
\hline \multirow[b]{2}{*}{ Variable } & \multirow{2}{*}{$\begin{array}{l}\text { Flower } \\
\text { clusters } \\
\text { (no./tree) }\end{array}$} & \multirow{2}{*}{$\begin{array}{c}\text { Flower } \\
\text { intensity } \\
\left(\text { no. } / \mathrm{cm}^{2}\right)\end{array}$} & \multirow{2}{*}{$\begin{array}{c}\text { Fruit set } \\
\text { (no./tree) }\end{array}$} & \multicolumn{2}{|c|}{ Leaf } \\
\hline & & & & $\mathrm{N}$ & $\mathrm{P}$ \\
\hline$\overline{P \text { rate }(\mathrm{g} / \text { tree })}$ & & & & \multicolumn{2}{|c|}{$(\% d r y w t)$} \\
\hline 0 & 42.0 & 15.8 & 13.7 & 2.83 & 0.19 \\
\hline 17.5 & 83.8 & 31.7 & 23.1 & 2.77 & 0.23 \\
\hline 35.0 & 89.3 & 33.6 & 26.6 & 2.96 & 0.28 \\
\hline $\begin{array}{l}\text { SE } \\
\text { P contrasts }\end{array}$ & 5.4 & 1.9 & 1.8 & 0.04 & 0.01 \\
\hline $\begin{array}{l}\text { P contrasts } \\
\text { Linear }\end{array}$ & $* * *$ & ** & $* * *$ & * & $* * * *$ \\
\hline Quadratic & $*$ & $*$ & NS & $*$ & NS \\
\hline $\mathrm{N} \times \mathrm{P}$ & NS & NS & NS & NS & NS \\
\hline
\end{tabular}

NS,*,**,***,****Nonsignificant or significant at $P=0.05,0.01,0.001$, or 0.0001 , respectively.

¥ May-1 Oct.) for $1.5 \mathrm{hr}$ each day through one 4-liter $\cdot \mathrm{hr}^{-1}$ emitter, located within 0.5 $\mathrm{m}$ of each tree.

Insect, disease, and weed control were undertaken in the three experimental plantings according to standard commercial practices (British Columbia Ministry of Agr. and Fisheries, 1989).

For all trees, trunk diameter was measured at $0.3-\mathrm{m}$ height above the graft union, just after planting and the next year in March (expts. 1 and 2) or on 1 May (expt. 3) before the onset of extensive new growth. The number of flower clusters on each tree of each experiment was counted within 2 to 3 days of full bloom (the 1st week of May) and 1st year after planting. Flower intensity, a measure of flowering independent of variation in tree size, was calculated as number of flowers per square centimeter of crosssectional trunk area measured at the $0.3-\mathrm{m}$ height. The number of fruit was counted 31 May (expt. 2), 26 June (expt. 1), or 5 July (expt. 3).

In mid-July of the first growing year, composite leaf samples, comprised of 30 leaves collected from the mid-third portion of extension shoots, were collected from each plot of expts. 2 and 3 . In expt. 1, insufficient leaf sample was available from the single tree plots; therefore, leaves were pooled from three similarly treated trees to result in four composite samples per treatment. The samples were oven-dried at $65 \mathrm{C}$ and ground in a stainless steel mill. Nitrogen was measured on a 100-mg leaf subsample using the Assn. of Official Agricultural Chemists Kjeldahl method (1965). A 250-mg subsample was digested for $0.5 \mathrm{hr}$ on a block digester at $350 \mathrm{C}$ before $\mathrm{P}$ determination, using the autoanalyzer method involving the formation of a phosphomolybdenum blue complex and before $\mathrm{N}$ determination using the calorimetric methods involving the formation of an ammonium-salicylate complex (Technicon Autoanalyzer II Industrial Method no. 334$74 \mathrm{~A} / \mathrm{A})$.

Analysis of variance was performed on all data according to the individual experimental designs.

Application of $\mathrm{P}$ in the year of planting increased the number of flower clusters the subsequent year in all three experiments ( $\mathrm{Ta}$ bles 1-3). In expt. 1 (Table 1), planting hole application of monoammonium phosphate increased by more than 4-fold the number of flower clusters per tree the following spring. This increase was not a consequence of increased tree size, since tree growth was unaffected by $\mathrm{P}$ (data not shown). As a result, flower intensity was also increased by $\mathrm{P}$

In expt. 2, there were differences in response to planting hole $\mathrm{P}$ by the cultivarrootstock combinations, as indicated by a significant $\mathrm{P} \times$ cultivar-rootstock interaction (Table 2). 'Jonamac' and 'Jonagold' on M.26 rootstock had 2.5- and 3.8-fold increases, respectively, in the number of flowers. In contrast, 'Jonagold' on M.4 produced few flowers in year 2, with no significant response to $\mathrm{P}$. Phosphorus also affected tree growth in this experiment, with lst-year trunk cross-sectional area increased by $\mathrm{P}$ for 'Jonagold' on M.26, decreased for 'Jonagold' on M.4, and unaffected for 'Jonamac' on M.26 (data not shown). The relative differences in tree size were small compared to changes in the number of flower clusters per tree, with the result that observed differences in flowering can be attributed to effects of planting hole P.

In expt. 3 , involving the addition of various rates of $\mathrm{N}$ and $\mathrm{P}$ fertilizer with irrigation water, the number of flower clusters/tree measured the subsequent spring showed significant linear and quadratic increases as the $\mathrm{P}$ fertilizer applied in the 1st year increased (Table 3). The number of flower clusters almost doubled as $\mathrm{P}$ addition increased from $\mathrm{O}$ to $17.5 \mathrm{~g} /$ tree. Little additional increase in flower number was observed for $35 \mathrm{~g} \mathrm{P} /$ tree. In contrast, an increase in $\mathrm{N}$ fertilization from 23.5 to $47 \mathrm{~g} /$ tree did not affect the number of flowers, flower intensity, or fruit set (data not shown). -First-year trunk cross-sectional area was also linearly increased by $\mathrm{P}$ with greatest growth at $35 \mathrm{~g} \mathrm{P} /$ tree (data not shown). Despite the differential growth associated with $\mathrm{P}$ additions, flower intensity showed the same response to $\mathrm{P}$ fertilization as did number of flowers. This implied, as in the other experiments, that the increase in flower number was not due only to an increase in tree size.

The increased number of flower clusters formed in the 2nd year was associated with higher rates of 1 st-year $\mathrm{P}$ fertilization, regardless of whether the fertilizer was placed in the planting hole or applied through the irrigation water. These results are consistent with several other studies that have associated increased initial flower production of 'Cox Orange Pippin' with an increase in $\mathrm{P}$ concentration from 0.25 to 4.0 meq $\mathrm{PO}_{4} /$ liter in nutrient solution sand culture studies (Bould and Parfitt, 1973) or to relatively high rates of $\mathrm{P}$ applied in the planting hole (Taylor, 1975) and used in association with daminozide (Williams and Thompson, 1979). Increased flowering of apple trees has also been associated with increased supply of $\mathrm{NH}_{4}-\mathrm{N}$ (Grasmanis and Leeper, 1967) with duration and timing of $\mathrm{NH}_{4}-\mathrm{N}$ treatment not critical (Grasmanis and Edwards, 1974). Since we used $\mathrm{NH}_{4}$-phosphate fertilizers in all experiments and made no subsequent measurements of $\mathrm{NH}_{4}-\mathrm{N}$ in the soil, a possible $\mathrm{NH}_{4}{ }^{-}$ $\mathrm{N}$ effect on initial flower formation cannot be completely dismissed in our experiments. This, however, is unlikely since planting hole and fertigation treatments in which no $\mathrm{P}$ was applied had few flowers even though initially supplied with $\mathrm{NH}_{4}-\mathrm{N}$ as either ammonium nitrate or ammonium polyphosphate.

The mechanism of the P effect on lst-year flowering of apple is unknown. However, 


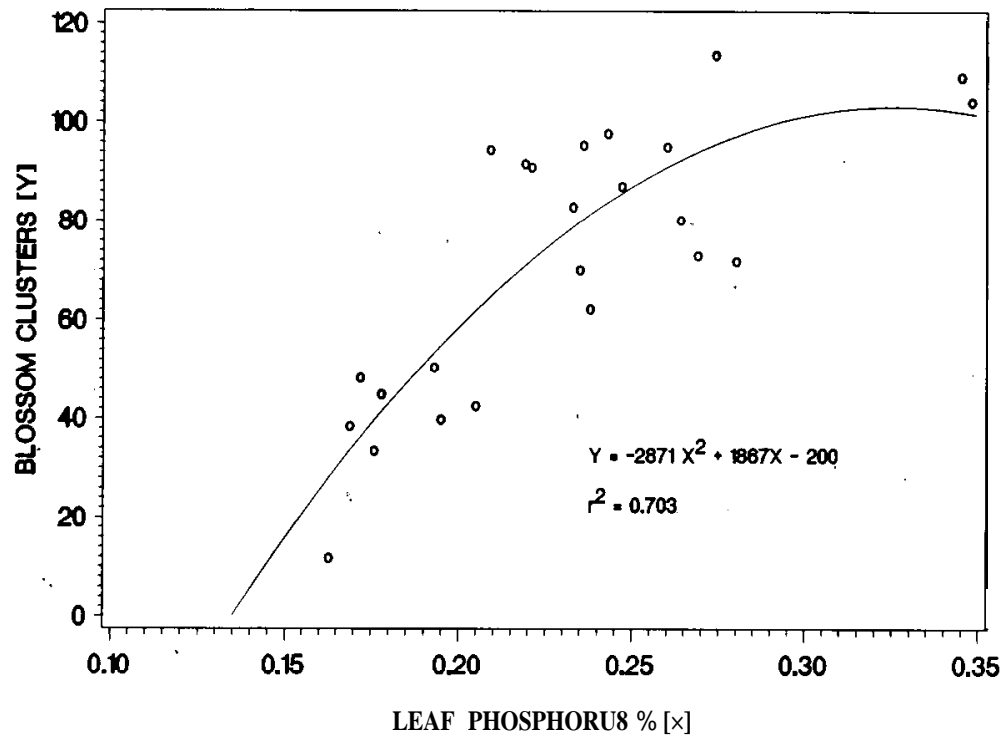

Fig. 1. Relationship between 1st-year midterminal leaf $\mathrm{P}$ concentration and number of flower clusters in the 2nd year for fertigated 'Summerland McIntosh' apple on M.9 rootstock (expt. 3).

for sycamore seedlings (Platanus occidentalis L.) correlations exist between P supply and cytokinin levels (Dhillon, 1978), while the number of flowers and cytokinin level of tomato (Lycopersicon esculentum Mill.) are related (Menary and van Staden, 1976). Increased initial root length is a known consequence of high $\mathrm{P}$ supply to wild cherry (Prunus avium L.) (Neilsen et al., 1990). A similar increase in root growth in apple could be associated with increased cytokinin levels contributing to the enhancement of flower initiation. The longevity of the response to $\mathrm{P}$ would, therefore, depend on the persistence of increased root length and cytokinin activity from season to season. Several of the previous studies have indicated a multiseason persistence in the $\mathrm{P}$ response (Bould and Parfitt, 1973; Taylor, 1975)

First-year $\mathrm{P}$ fertilization and increased number of flower clusters resulted in increased fruit set indicative of a 1st-year yield response to $\mathrm{P}$ (Tables 1-3). Results from expt. 2 indicate that the response varies with cultivar-rootstock combination since 'Jonagold' on M.4, a less-precocious fruiting combination, set very few fruit. The increase in fruit set was variable, ranging from an average $10 \%$ (expt. 1) to $30 \%$ (expts. 2 and 3 ) of total flowers. Yield response to $P$ has not been widely reported for tree fruits (Childers, 1966) although increasing the rate of superphosphate applied at planting time stimulated tree growth, fruit set, and yield in four successive growing seasons in Australia (Taylor and Goubran, 1975). Neilsen et al. (1989) also demonstrated that P likely increased initial diameter growth and the first 2 years of yield of 'McIntosh' and 'Delicious' apple trees irrigated with wastewater high in P. In contrast, no response to trickleirrigated ammonium polyphosphate was measured for mature fruiting 'Anna' apple in Israel (Klein and Spieler, 1987a) suggesting that response to $\mathrm{P}$ may vary with tree age. The longevity of yield response to $\mathrm{P}$ cannot be assessed from these experiments but is an important question requiring further research. Variation in longevity of yield response to $\mathrm{P}$ for young trees may depend, for example, on persistence of increased root length (or cytokinin level) as previously discussed.

Leaf $\mathrm{N}$ concentration was adequate in the three experiments, unaffected by planting hole treatments that involved application of the same rate of $\mathrm{N}$ (Tables 1 and 2), but was also unaffected by increasing the rate of $\mathrm{N}$ applied with the trickle irrigation system (data not shown). Thus, $\mathrm{N}$ nutrition seemed unrelated to the observed changes in flower initiation. First-year leaf $\mathrm{P}$ concentration averaged $0.26 \%$ and $0.37 \%$ for $\mathrm{P} 2$ trees in expt. 1 (Table 1) and expt. 2 (Table 2), respectively. In expt. 3, a linear increase in leaf $\mathrm{P}$ concentration from $0.19 \%$ to $0.28 \%$ occurred as trickle-irrigated $\mathrm{P}$ increased from 0 to $35 \mathrm{~g} \mathrm{P} /$ tree (Table 3 ). A highly significant curvilinear relationship between number of flower clusters in year 2 and lst-year $\mathrm{P}$ concentration occurred for the fertigated trees when the data are expressed independent of treatments on a plot basis (Fig. 1). Flower number was almost linearly related to leaf $\mathrm{P}$ concentration in the $\mathrm{O} .15 \%$ to $0.28 \%$ range but appeared to reach a plateau above $0.28 \%$. A similar relationship between number of flowers and leaf $\mathrm{P}$ concentration was measured for young virus-tested 'Cox's Orture pot experiments (Bould and Parfitt, 1973). Together, these results indicate a desirable midsummer, midterminal leaf $\mathrm{P}$ concentration near $0.30 \%$, much higher than the $0.15 \%$ leaf $\mathrm{P}$ concentration normally considered adequate for apples (Shear and Faust, 1980). A direct association between initiation of apple flower clusters and $\mathrm{P}$ nutrition is also implied. Further study, such as that recently described for grapes (Skinner and Mathews, 1989) needs to investigate whether variation in timing of $\mathrm{P}$ supply through the growing season affects the improvements in reproductive development associated with a high $\mathrm{P}$ regime.

In summary, the creation of high soil soange Pippin' on MM. 104 grown in sand cul- lution $\mathrm{P}$ concentrations in the root zone of newly planted apple trees, whether by fertigation or application of high rates of $\mathrm{P}$ in the planting hole, increases blossoming and fruit set the next year. Phosphorus fertilization of newly planted trees with leaf $\mathrm{P}$ concentration near $0.30 \%$ for 'McIntosh' was associated with acceleration of the onset of fruiting. The mechanism and longevity of this response to $\mathrm{P}$ needs further assessment, although fertigation would offer a convenient method of periodically increasing tree $\mathrm{P}$ status in coarse-textured soils. It would also seem desirable to maintain the leaf $\mathrm{P}$ concentrations of young apple trees at values above those normally considered adequate for mature trees.

\section{Literature Cited}

Association of Official Agricultural Chemists. 1965. Official methods of analysis. Assn. Offic. Agr. Chem., Washington, D.C.

Bould, C. and R.I. Parfitt. 1973. Leaf analysis as a guide to the nutrition of fruit crops. X. Magnesium and phosphorus sand culture experiments with apple. J. Sci. Food Agr. 24:175185.

British Columbia Ministry of Agriculture and Fisheries. 1989. Tree fruit production guide for interior districts. Country Life Ltd., Surrey, B.C.

Childers, N.F. (cd.). 1966. Nutrition of fruit crops, temperate, subtropical, tropical. Horticultural Publications. Rutgers, New Brunswick, N.J.

Dhillon, S.S. 1978. Influence of varied phosphorus supply on growth and xylem sap cytokinin level of sycamore (Platanus occidentals L.) seedlings. Plant Physiol. 61:521-524.

Grasmanis, V.O. and G.R. Edwards. 1974. Promotion of flower initiation in apple trees by short exposure to the ammonium ion. Austral. J. Plant Physiol. 1:99-105.

Grasmanis, V.O. and G.W. Leeper. 1967. Ammonium nutrition and flowering of apple trees. Austral. J. Biol. Sci. 20:761-767.

Kelley, C.C. and R.H. Spilsbuty. 1949. Soil survey of the Okanagan and Similkameen Valleys. British Columbia Dept. Agr. and Dominion Dept. Agr. Ottawa, Ont.

Klein, I. and G. Spieler. 1987a. Fertigation of apples with nitrate or ammonium nitrogen under drip irrigation. I. Tree performance. Commun. Soil Sci. Plant Anal. 18:311-322.

Klein, I. and G. Spieler. 1987b. Fertigation of apples with nitrate or ammonium nitrogen under drip irrigation. II. Nutrient distribution in the soil. Commun. Soil Sci. Plant Anal. 18:323339.

Menary, R.C. and J. van Staden. 1976. Effect of phosphorus nutrition and cytokinins on flowering in the tomato, Lycopersicon esculentum. Mill. Austral. J. Plant Physiol. 3:201-205.

Neilsen, G. H., D.S. Stevenson, J.J. Fitzpatrick, and C.H. Brownlee. 1989. Nutrition and yield of young apple trees irrigated with municipal waste water. J. Amer. Soc. Hort. Sci. 114:377383.

Neilsen, G.H., D. Neilsen, and D. Atkinson. 1990 Top and root growth and nutrient absorption of Prunus avium $\mathrm{L}$. at two soil $\mathrm{pH}$ and $\mathrm{P}$ levels. Plant and Soil. 121:137-144.

Sewell, G. W. F., D.A. Preece, and R.F. Elsey. 1988. Apple replant disease: the influence of soil phosphorus and other factors on the growth responses of apple seedlings to soil fumigation with chloropicrin. Ann. Applied Biol. 113:605615.

Shear, C.B.and M. Faust. 1980. Nutritional ranges in deciduous tree fruits and nuts. Hort. Rev. 
2:142-163.

Skinner, P.W. and M.A. Mathews. 1989. Reproductive development in grape (Vitis vinifera L.) under phosphorus-limited conditions. Scientia Hort. 38:49-60.

Slykhuis, J.T. and T.S.C. Li. 1985. Responses of apple seedlings to biocides and phosphate fer- tilizers in orchard soils in British Columbia. Can. J. Plant Pathol. 7:294-301.

Taylor, B.K. 1975. Response of newly planted peach and apple trees to superphosphate. Austral. J. Agr. Res. 26:521-528.

Taylor, B.K. and F.H. Goubran. 1975. The phosphorus nutrition of the apple tree. I. Influence of rate of superphosphate on the performance of young trees. Austral. J. Agr. Res. 26:843853.

Williams, J.M. and A.H. Thompson. 1979. Effect of phosphorus, nitrogen and daminozide on growth and first fruiting of dwarf apple trees. HortScience 14:703-704. 